\title{
CHANGES IN CONTENTS OF PHENOLIC COMPOUNDS (SINAPIC ACID DERIVATIVES) IN SEEDS OF BRASSICA NAPUS L. UNDER ADVERSE STORAGE CONDITIONS
}

\author{
Aleksander Siger $^{1 \bowtie}$, Marzena Gawrysiak-Witulska², Jolanta Wawrzyniak² \\ ${ }^{1}$ Department of Food Biochemistry and Analysis, Poznań University of Life Sciences \\ Wojska Polskiego 28, 60-637 Poznań, Poland \\ ${ }^{2}$ Institute of Food Technology of Plant Origin, Poznań University of Life Sciences \\ Wojska Polskiego 28, 60-637 Poznań, Poland
}

\begin{abstract}
Background. The quality of rapeseed oil depends to a considerable degree on raw material quality. Negligence in maintaining the appropriate conditions during long-term rapeseed storage (excessively high humidity and temperature) may contribute to a deterioration of seed quality, as a result of microbial growth and changes in native antioxidant contents. The aim of this study was to investigate the effect of inappropriate storage conditions on changes in sinapic acid derivative content, which is the main phenolic compound in rapeseeds.

Material and methods. The material used for tests was canola cv. PR 46 W14. Seeds with a 13.5\% moisture content were stored for 21 days in a thermo-hygrostat chamber, ensuring rapeseed storage under constant humidity and temperature conditions. In this study, the level of mould fungi was analysed using the plate method, while those of sinapic acid derivatives were determined using the HPLC-DAD method.

Results. Intensive growth of mould fungi in the rapeseeds was observed after 6 days of storage. Changes were recorded in sinapic acid derivative contents, which are the main phenolic compounds in rapeseed. The level of phenolic compounds found in the bound form (sinapin; sinapic acid methyl ester; 1,2-disinapoyldihexoside; 1,2-disinapoyl-hexoside and 1,2,2'-trisinapoyl-dihexoside) decreased. At the same time, an increase was recorded in trans-sinapic acid content (by 63\%).

Conclusion. Both qualitative and quantitative changes in phenolic compounds may be connected with the development of fungal microflora in stored rapeseeds. Only adequate storage conditions for the oil raw material, such as rapeseeds, may ensure good quality in the final product, in this case, rapeseed oil.
\end{abstract}

Keywords: rapeseed, sinapic acid, phenolic compounds, storage, postharvest

\section{INTRODUCTION}

Rapeseed oil is one of the three most commonly produced and consumed oils worldwide, ranking third immediately after palm oil and soybean oil. To a considerable extent its quality is determined by the raw material from which it is produced. The chemical composition of rapeseeds (nutrient and bioactive compound contents) determines their technological and nutritional quality. Due to their morphological and anatomical structure, rapeseeds are very sensitive material, reacting with a decrease in quality to both inappropriate harvesting methods and the technology and conditions of postharvest processing (Tys and

『aleksander.siger@up.poznan.pl 
Siger, A., Gawrysiak-Witulska, M., Wawrzyniak, J. (2018). Changes in contents of phenolic compounds (sinapic acid derivatives) in seeds of Brassica napus L. under adverse storage conditions. Acta Sci. Pol. Technol. Aliment., 17(4), 367-375. http://dx.doi. org/10.17306/J.AFS.2018.0596

Rybacki, 2001). The stages of rapeseed postharvest processing include purification, drying and storage (Janowicz, 2005; Tańska and Rotkiewicz, 2003). The scope of adverse chemical and biochemical changes occurring during rapeseed storage is determined first of all by their excessive moisture content. Increased seed moisture content significantly reduces safe storage time, causing the risk of mould development (Pronyk et al., 2006; Wawrzyniak et al., 2018a) and rapeseed contamination with secondary metabolites of these microorganisms, i.e. mycotoxins, exhibiting toxicity in relation to humans and animals (Hussein and Brasel, 2001). Depending on the conditions (temperature, humidity as well as the degree of damage and contamination), during rapeseed storage the technological quality of seeds frequently deteriorates, while changes take place in the contents of bioactive compounds. An increase in storage temperature to $30^{\circ} \mathrm{C}$ contributes to an increase in the level of hydrolysis and lipid oxidation products in rapeseeds and influences their fatty acid profile (Krasucki et al., 2002). These processes also cause changes in the level of biologically active compounds. Literature sources present data concerning the effect of postharvest processing (near ambient and high temperature drying) and inappropriate rapeseed storage conditions on tocochromanols or phytosterols. Studies conducted by Gawrysiak-Witulska et al. (2012) showed a significant effect of drying conditions and storage time on contents of plant sterols in rapeseeds. The authors showed a decrease in total sterol content by $6-20 \%$ in the case of near ambient drying and by $14-40 \%$ for drying with heated air in a temperature range of $60-120^{\circ} \mathrm{C}$ (the higher the drying temperature, the greater the decrease). In studies concerning tocopherols the authors showed losses of these compounds during near-ambient-temperature drying amounting to $6-11 \%$, while for high-temperature drying they amounted to 4-8\% (Gawrysiak-Witulska et al., 2009; 2015).

A unique characteristic of rapeseeds is connected with their 10-fold greater phenolic content in comparison to seeds of other oil crops. These compounds are primarily sinapic acid derivatives. Sinapic acid is the main phenolic compound in rapeseeds, accounting for over $70 \%$ of total content of free phenolic acids, along with its derivatives, e.g. sinapin, amounting to $1-2 \%(\mathrm{w} / \mathrm{w})$ seed weight (Bell, 1993;
Kozlowska et al., 1983). Free phenolic acids constitute only approx. $10 \%$ of the total phenolic content of rapeseeds. Other phenolic compounds that are derivatives of sinapic acid identified in rapeseeds include 1-O-b-D-glucopyranosyl sinapate with strong antioxidative properties (Wanasundara et al., 1994); 3-O-hexoside-kaempferol, 3-dihexoside-7-sinapoyl-hexoside kaempferol and 3-hexoside-7-sinapoyl hexoside kaempferol (Siger et al., 2013); and sinapic acid methyl ester (Thiyam et al., 2009). In turn, Baumert et al. (2005) in Brassica napus seeds recorded the presence of one of the glucose esters $(1,6$-di-O-sinapoylglucose), two gentiobiose esters (1-O-caffeoylgentiobiose and 1,2,6'-tri- $O$-sinapoylgentiobiose) as well as two kaempferol conjugates [4'-(6-O-sinapoylglucoside)-3,7-di- $O$-glucoside and 3-O-sophoroside-7-O-(2-O-sinapoylglucoside)]. Koski et al. (2003) identified vinylsyringol (canolol), a compound formed under the influence of elevated pressure and temperature in the course of oil extraction. These compounds are ascribed high antioxidant and free radical scavenging activity, with some of them exhibiting bactericidal properties; additionally, they protect DNA, as well as fats and proteins against oxidation (Engels et al., 2012; Kuwahara et al., 2004; Mariod et al., 2015; Siger and Józefiak 2016; Siger et al., 2015; 2016; Rękas et al., 2017). In earlier studies conducted to determine changes in the technological and microbiological quality of rapeseeds during selfheating, the authors of this paper observed significant changes in the levels of phenolic compounds. However, those analyses only concerned free phenolic acid content (Gawrysiak-Witulska et al., 2018). According to the authors, it is advisable to investigate the effect of adverse storage conditions of rapeseeds on the levels of the main phenolic acids, particularly derivatives of sinapic acid.

\section{MATERIALS AND METHODS}

\section{Chemicals}

Phenolic acid standards and methanol (HPLC-grade) were purchased from Sigma (St. Louis, MO). Acetonitrile and orthophosphoric acid (both HPLC-grade) were obtained from Merck (Darmstadt, Germany). All other solvents and chemicals used in this study were of analytical grade. Deionized water was used 
in resin-based column chromatography, while ultrapure water purified via the Milli-Q system (Millipore, Bedford, USA) was used during HPLC analyses.

\section{Materials}

The testing material was canola cv. PR $46 \mathrm{~W} 14 \mathrm{ob}-$ tained directly after harvest from the Złotniki Experimental Station belonging to the Poznań University of Life Sciences, Poland. Prior to the experiments, rapeseeds were wetted to achieve $13.5 \%$ moisture content. Seeds prepared in this way were stored at $25^{\circ} \mathrm{C}$ in a thermo-hygrostat chamber providing constant humidity and temperature. During storage, seed samples were collected for analyses after 6,14 and 21 days. The control comprised harvested seeds with a $7 \%$ moisture content.

Humidity and temperature conditions for seed storage were selected based on previous studies on the kinetics of mould growth in rapeseed ecosystems and changes in the technological quality of seeds stored under various temperature and humidity conditions (Wawrzyniak et al., 2018a). According to the studies cited, the seed storage conditions applied in this experiment promote activation of fungal microflora and cause an increase in free fatty acid content; nevertheless, after 21 days of storage seeds still retain adequate technological quality.

\section{Determination of seed moisture content}

The seed moisture content was determined using an electronic moisture analyser (MA150 Sartorius Mechatronics, Poland). The moisture analyser used a reference standard prepared by drying a 5 -g sample to a constant mass at a temperature of $115^{\circ} \mathrm{C}$. The measuring accuracy of the analyser was $0.05 \%$ w.b. (wet basis). The apparatus was calibrated using the oven method according to the AOCS Official Method Ba 2a-38 with the prepared reference as stated above.

\section{Methanol extracts of phenolic compounds}

All samples were defatted using an automatic Soxhlet Büchi Extraction System B-811 (Büchi Labortechnik AG, Flawil, Switzerland). The extraction with $n$-hexane was run for four hours. To obtain rapeseed phenols, each sample was extracted three times with $80 \%$ methanol. In brief, $5 \mathrm{~g}$ of the sample was extracted with $50 \mathrm{ml} 80 \%$ methanol in three separate stages for a total of 30 minutes at $50^{\circ} \mathrm{C}$. After centrifugation (10 min at $5000 \mathrm{~g}$ ) (model 6K15, Sigma, Osterode am Harz, Germany), the precipitate was reextracted twice following the same steps. The three supernatants were combined and evaporated under reduced pressure using an R-215 Rotavapor (Büchi Labortechnik AG, Flawil, Switzerland) to a volume of $50 \mathrm{ml}$.

\section{HPLC quantification of phenolic compounds}

Phenolic compounds were identified and quantified using analytical reversed-phase high performance liquid chromatography (HPLC - Waters, Milford, MA) on an $\mathrm{XBridge}^{\mathrm{TM}} \mathrm{C} 18$ reversed-phase column (4.6 $\times$ $100 \mathrm{~mm} ; 3.5 \mu \mathrm{m}$ ) (Waters, Milford, MA). A gradient program was used, combining solvent A (acetonitrile: water $50: 50 \mathrm{v} / \mathrm{v}$ ) and solvent $\mathrm{B}$ (water adjusted to $\mathrm{pH}$ 2.7 with orthophosphoric acid) as follows: $0-50 \%$ A (60 min) and $50-0 \%$ A (9 min). The flow rate was $1.0 \mathrm{ml} / \mathrm{min}$. The injection volume was $10 \mathrm{~mL}$, while the column temperature was maintained at $20^{\circ} \mathrm{C}$. The signal was monitored at $200-600 \mathrm{~nm}$ with a diode array detector (DAD) (UV-VIS Waters, Milford, MA). Qualitative identification and quantitative determination of phenolic acids were carried out by comparing retention times and diode array spectral characteristics with the corresponding standards. The phenolic compound content (sinapic acid derivatives) in all samples was calculated on the basis of calibration curve made for sinapic acid standard. Results were expressed as $\mathrm{mg}$ sinapic acid per $100 \mathrm{~g}$ of the sample. The compounds were also identified using HPLC/ESI/MS ${ }^{\mathrm{n}}$ following the methodology described in earlier studies (Siger et al., 2013).

\section{Mould growth assessment}

The number of colony-forming units (CFU) of moulds per $1 \mathrm{~g}$ of seeds was counted according to the PN-ISO 21527-2:2008 standard. During microbiological analysis, serial dilutions were prepared following the PN-EN-ISO 6887-1:2000 standard. Samples of $1 \mathrm{ml}$ were spread onto duplicate sterilised plates and covered with YGC Agar containing glucose, agar, yeast extract and chloramphenicol $\left(100 \mu \mathrm{g} \mathrm{l}^{-1}\right)$. After 3 days of incubation, the CFUs of moulds were evaluated using a colony counter. All treatments were replicated three times. 


\section{Statistical analysis}

The results are presented as means \pm standard deviation from three replicates of each experiment. A $P$-value $<0.05$ was used to denote significant differences between mean values determined by the analysis of variance (ANOVA) with the assistance of the Statistica 13.0 software (StatSoft, Inc., Tulsa, OK).

\section{RESULTS AND DISCUSSION}

The primary quality attribute of rapeseed for processing is expressed as an acid number, which should not exceed $3 \mathrm{mg} \mathrm{KOH} / \mathrm{g}$ fat (PN-R-66151:1990). In our earlier studies on the storage of seeds with a $15 \%$ moisture content at $25^{\circ} \mathrm{C}$, we showed a high increase in free fatty acid content. Under these conditions, the threshold acid number value ( $3 \mathrm{mg} \mathrm{KOH} / \mathrm{g}$ ) was already exceeded after approx. 10 days of storage. After 6 days of seed storage, the level of this indicator was $2.4 \mathrm{mg} \mathrm{KOH} / \mathrm{g}$, while after 18 days of storage it was $6.4 \mathrm{mg} \mathrm{KOH} / \mathrm{g}$ (Gawrysiak-Witulska et al., 2011). Adequate rapeseed storage conditions, particularly a seed moisture content of max. $7 \%$, result in a slower increase in free fatty acid content and a considerably extended storage time. In turn, seeds with a moisture content of $9-10 \%$ may be stored for 3 months (Salunkhe et al., 1992). Results reported by Flakelar et al. (2018) indicate that the accumulation of free fatty acids will remain within the admissible limits for 10 months on condition the seed moisture content, oil exposure to light and exposure to extreme temperatures are limited to the minimum. According to Matthäus (2013), seeds with a 7\% moisture content are stable during 9-month storage. A higher seed moisture content significantly reduces the time of their safe storage, providing an environment promoting growth of mould fungi and rapeseed contamination with mycotoxins. The changes in the CFU of moulds in rapeseed with a moisture content of $13.5 \%$ w.b. stored at $25^{\circ} \mathrm{C}$ are presented in Figure 1. There are three characteristic stages in the curve of mould growth, i.e. the lag phase, exponential growth and the stationary phase. A similar pattern of mould development was observed in barley grain and rapeseed ecosystems by Wawrzyniak et al. (2013; 2018a; 2018b). The decrease in CFU of moulds in the initial period of seed storage (in the lag phase of mould growth) was associated with the fungi's adaptation to environmental

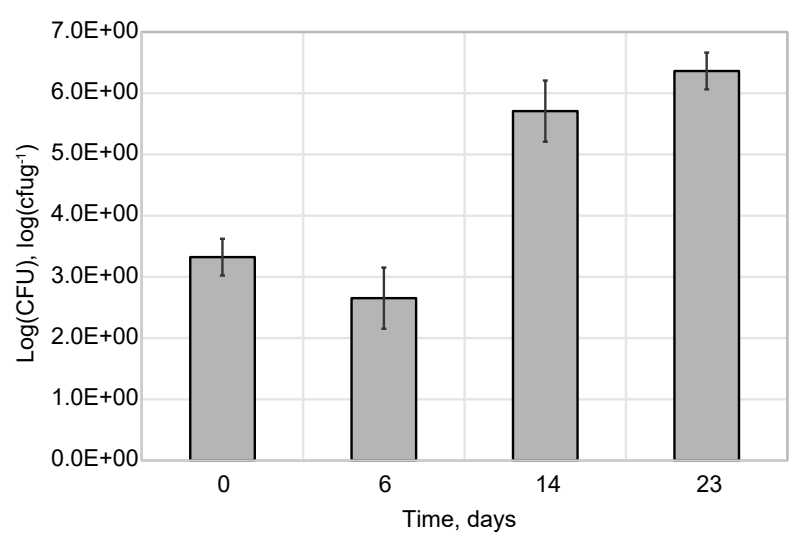

Fig. 1. Changes in fungal contamination of rapeseeds with $13.5 \%$ moisture content stored at $25^{\circ} \mathrm{C}$ for 21 days

conditions. After 6 days of storage, the fungal metabolic apparatus was fully activated and the fungi developed at a maximum rate. As a result, the size of the fungal population increased rapidly. After 15 days of storage, the rate of fungal growth decreased and mould growth reached the stationary phase of fungal development. The results obtained are in agreement with the findings from the previous study. While investigating the rapeseed ecosystem with a moisture content of $13.1 \%$ w.b. stored at $24^{\circ} \mathrm{C}$, Wawrzyniak et al. (2018a) also observed the beginning of fungal activity after 6 days of storage, whilst the stationary phase of the mould development began after 18 days.

A high seed moisture content and an elevated storage temperature result in an intensification of adverse chemical and biochemical changes. Enhanced hydrolytic processes or growth of mould fungi also cause changes in the levels of native bioactive compounds. In our earlier studies, we showed that adverse storage conditions (10-15\% moisture content and temperature of $25-30^{\circ} \mathrm{C}$ ) produce a statistically significant reduction in the level of lipophilic compounds such as tocochromanols and phytosterols (Gawrysiak-Witulska et al., 2012; 2015). Flakelar et al. (2018) also observed losses of phytosterols; however, they showed no statistically significant changes in the levels of individual phytosterols or their total contents in the function of temperature. They also showed that phytosterol losses were similar, irrespective of the fact whether their content was analysed in the samples stored as seeds or 
Siger, A., Gawrysiak-Witulska, M., Wawrzyniak, J. (2018). Changes in contents of phenolic compounds (sinapic acid derivatives) in seeds of Brassica napus L. under adverse storage conditions. Acta Sci. Pol. Technol. Aliment., 17(4), 367-375. http://dx.doi. org/10.17306/J.AFS.2018.0596

Table 1. Contents of phenolic compounds (derivatives of sinapic acid) in rapeseeds differing in their fungal contamination levels

\begin{tabular}{|c|c|c|c|c|c|}
\hline \multirow[t]{2}{*}{ Compounds } & \multirow{2}{*}{$\begin{array}{l}\text { Retention time } \\
\text { min }\end{array}$} & \multicolumn{4}{|c|}{$\begin{array}{l}\text { Sinapic acid derivative content in the seeds of Brassica napus } \mathrm{L} \text {. } \\
\qquad \mathrm{mg} / 100 \mathrm{~g} \mathrm{~d} . \mathrm{m} .\end{array}$} \\
\hline & & 0 day & after 6 days & after 14 days & after 21 days \\
\hline Sinapin & 14.856 & $932.5 \pm 2.1^{\mathrm{c}}$ & $930.2 \pm 3.6^{\mathrm{c}}$ & $917.5 \pm 1.9^{\mathrm{b}}$ & $839.0 \pm 2.8^{\mathrm{a}}$ \\
\hline Unidentified compound & 22.007 & $71.2 \pm 0.7^{\mathrm{d}}$ & $38.8 \pm 0.2^{\mathrm{c}}$ & $28.5 \pm 0.5^{\mathrm{b}}$ & $21.5 \pm 0.6^{\mathrm{a}}$ \\
\hline 3-dihexoside-7-sinapoyl-hexoside kaempferol & 27.141 & $57.5 \pm 0.5^{\mathrm{a}}$ & $56.8 \pm 0.4^{\mathrm{a}}$ & $57.9 \pm 0.6^{\mathrm{a}}$ & $55.3 \pm 0.2^{\mathrm{a}}$ \\
\hline trans-sinapic acid & 30.361 & $163.6 \pm 0.2^{\mathrm{a}}$ & $207.4 \pm 0.6^{\mathrm{b}}$ & $252.1 \pm 0.2^{\mathrm{c}}$ & $266.5 \pm 0.7^{\mathrm{d}}$ \\
\hline cis-sinapic acid & 34.493 & $57.4 \pm 0.9^{\mathrm{a}}$ & $57.9 \pm 0.5^{\mathrm{a}}$ & $58.9 \pm 0.4^{\mathrm{a}}$ & $57.4 \pm 0.8^{\mathrm{a}}$ \\
\hline Sinapic acid methyl ester & 44.182 & $50.9 \pm 0.6^{\mathrm{b}}$ & $49.6 \pm 0.2^{\mathrm{b}}$ & $50.0 \pm 0.2^{\mathrm{b}}$ & $46.8 \pm 0.1^{\mathrm{a}}$ \\
\hline 1,2-disinapoyl-dihexoside & 47.687 & $67.9 \pm 0.4^{\mathrm{d}}$ & $49.8 \pm 0.8^{\mathrm{c}}$ & $40.7 \pm 0.2^{\mathrm{b}}$ & $31.3 \pm 0.3^{\mathrm{a}}$ \\
\hline 1,2-disinapoyl-hexoside & 50.164 & $24.5 \pm 0.5^{\mathrm{b}}$ & $23.4 \pm 0.5^{\mathrm{b}}$ & $24.2 \pm 0.2^{\mathrm{b}}$ & $21.7 \pm 0.5^{\mathrm{a}}$ \\
\hline 1,2,2'-trisinapoyl-dihexoside & 52.483 & $7.6 \pm 0.2^{\mathrm{c}}$ & $6.4 \pm 0.5^{\mathrm{b}}$ & $5.8 \pm 0.6^{\mathrm{a}}$ & $5.0 \pm 0.1^{\mathrm{a}}$ \\
\hline
\end{tabular}

*Contents are expressed as a sinapic acid equivalent.

Values (means \pm SD) with different index letters are statistically significantly different $(P<0.05)$.

oil. Moreover, they found that the rate of phytosterol degradation may be dependent on the composition of the oil being analysed. In the case of tocopherols, the authors showed that they were more stable than phytosterols in stored oil. The method of oil extraction was also crucial for tocopherol stability, with greater losses observed in the case of oil obtained by solvent extraction in comparison to pressing (Flakelar et al., 2018). Literature sources present scarce data on changes in the phenolic content of rapeseeds during storage. In our earlier studies, concerning the process of rapeseed self-heating in silos we analysed changes in free phenolic content (Gawrysiak-Witulska et al., 2018). In turn, this experiment was focused on the main group of phenolic compounds found in the seeds of cruciferous plant species, i.e. sinapic acid derivatives. In rapeseeds we identified such compounds as sinapin; 3-dihexoside-7-sinapoyl-hexoside kaempferol; trans-sinapic acid; cis-sinapic acid; sinapic acid methyl ester; 1,2-disinapoyl-dihexoside; 1,2-disinapoyl-hexoside and 1,2,2'-trisinapoyl-dihexoside. One compound (with the retention time of 22.007 minutes) was not identified. The results are presented in Table 1, while an example chromatogram showing the separation of phenolics is shown in Figure 3. It was found that in the control sinapin (at $932.5 \mathrm{mg} / 100 \mathrm{~g}$ d.m.) and trans-sinapic acid (163.6 mg/100 g d.m.) were the most abundant compounds. The levels of the other sinapic acid derivatives ranged from 7.6 to 67.9 $\mathrm{mg} / 100 \mathrm{~g}$ d.m. for 1,2,2'-trisinapoyl-dihexoside and 1,2-disinapoyl-dihexoside, respectively. Total phenolic compound content in rapeseeds amounted to 1433.1 $\mathrm{mg} / 100 \mathrm{~g}$ d.m. (Fig. 2). Storage of seeds with a $13.5 \%$

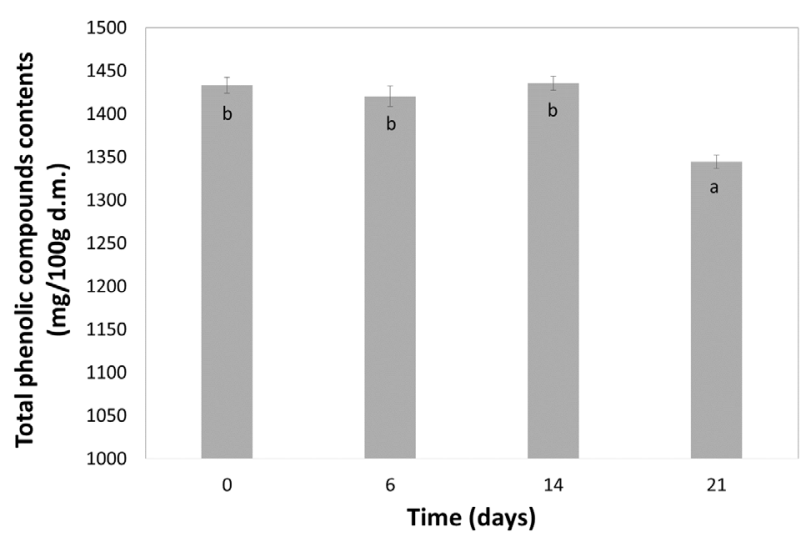

Fig. 2. Total phenolic content in seeds of Brassica napus L. during adverse storage conditions 


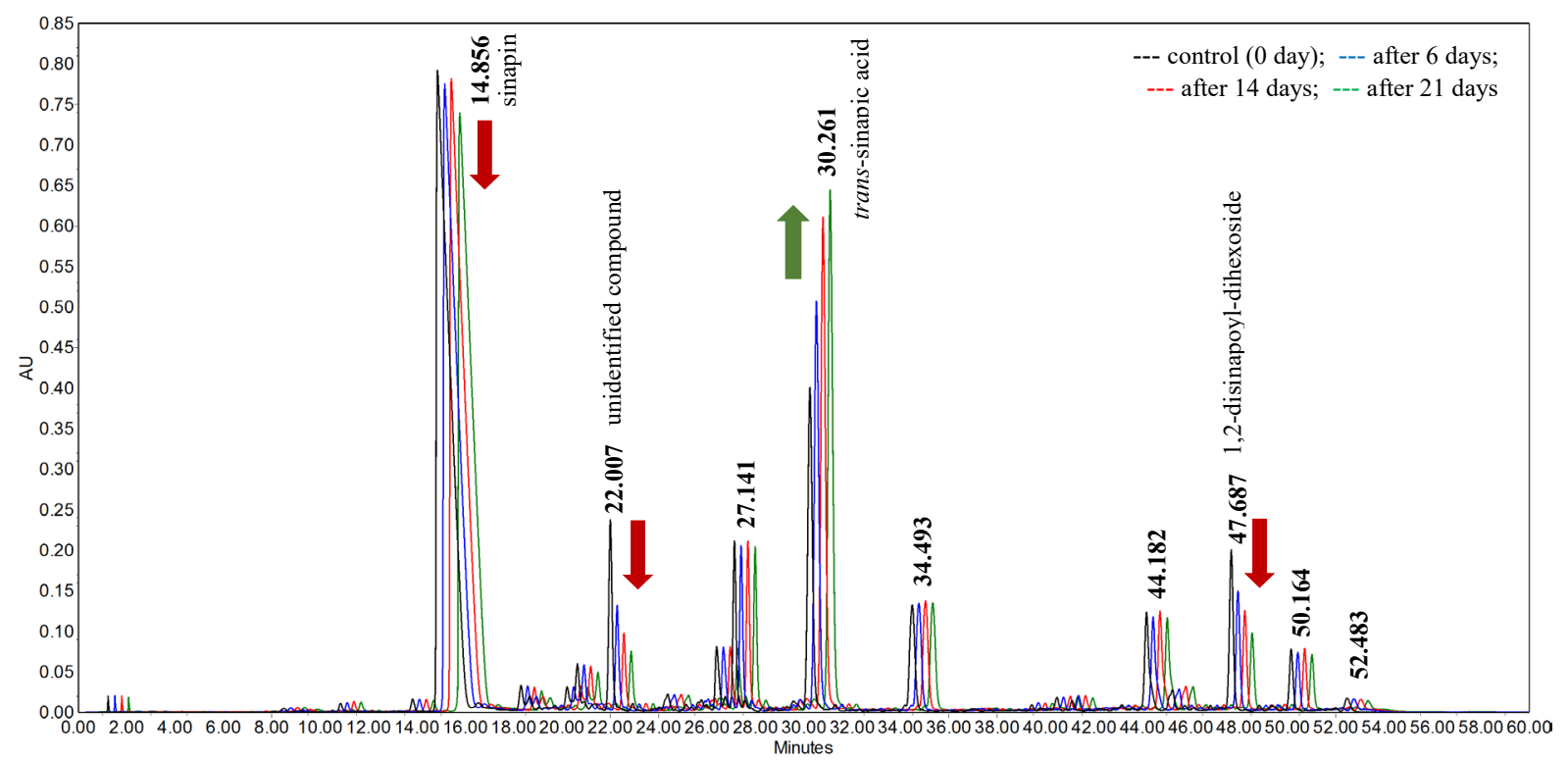

Fig. 3. A chromatogram of phenolic compounds in rapeseed for the control and after 6,14 and 21 days of storage

moisture content at $25^{\circ} \mathrm{C}$ also resulted in quantitative changes in individual sinapic acid derivatives (Table 1, Fig. 3). As early as after 6 days of storage statistically significant changes were recorded in the levels of trans-sinapic acid; 1,2-disinapoyl-dihexoside and $1,2,2^{\prime}$-trisinapoyl-dihexoside. The levels of the two latter compounds decreased by $27 \%$ and $16 \%$, respectively. In turn, the trans-sinapic acid content increased by $27 \%$. Prolonged storage under adverse conditions caused a further decrease in 1,2-disinapoyl-dihexoside and 1,2,2'-trisinapoyl-dihexoside content by another $18 \%$ and $9 \%$, respectively. Moreover, a statistical reduction was recorded in the level of sinapin to 917.5 $\mathrm{mg} / 100 \mathrm{~g} \mathrm{~d}$.m. After 21 days of storage the level of sinapin decreased by $10 \%$ in relation to the control. A considerable drop was recorded for 1,2-disinapoyldihexoside (by 54\%) in relation to the control. In the case of trans-sinapic acid, its level increased throughout the experiment (Fig. 3). After 21 days trans-sinapic acid content was $266.5 \mathrm{mg} / 100 \mathrm{~g}$ d.m. (an increase of $63 \%$ ) in relation to the control (Table 1). When analysing total sinapic acid derivative content its statistically lower level was recorded as late as after 21 days of storage. The value was $13485 \mathrm{mg} / 100 \mathrm{~g}$ d.m., which is equivalent to a $6 \%$ decrease in relation to the control (Fig. 2). When investigating the results of earlier studies concerning changes in free phenolic acid content at self-heating of rapeseed, we also showed an increase in trans-sinapic acid levels from 366.1 $\mathrm{mg} / \mathrm{kg}$ in the control to $1552.3 \mathrm{mg} / \mathrm{kg}$ in the sample collected from the geometrical centre of the silo (the location with the greatest risk of spoilage). The levels of protocatechuic, caffeic, $p$-coumaric and ferulic acids decreased in this experiment. Moreover, we also observed a more than 4-fold increase in p-hydroxybenzoic acid content (Gawrysiak-Witulska et al., 2018). Changes in the levels of native antioxidants in rapeseeds are caused to a considerable extent by auto-oxidation of lipids, whose level in rapeseeds may reach $50 \%$. However, in the case of seeds with a moisture content exceeding $6 \%$, the activity of hydrolytic and oxidative enzymes, such as lipoxygenases, starts to play a considerable role. Lipoxygenases belong to the subclass of dioxygenases containing iron; they catalyse oxidation of free or esterified polyenic fatty acids to hydroperoxides. Initial products of lipoxygenase activity may be degraded to various compounds, including aldehydes, ketones (characteristic aroma compounds) and alcohols. Intermediate products formed as a result of lipoxygenase activity may undergo cyclisation triggered by allenyl cyclooxygenase and this pathway leads to the formation of jasmonic acid and 
Siger, A., Gawrysiak-Witulska, M., Wawrzyniak, J. (2018). Changes in contents of phenolic compounds (sinapic acid derivatives) in seeds of Brassica napus L. under adverse storage conditions. Acta Sci. Pol. Technol. Aliment., 17(4), 367-375. http://dx.doi. org/10.17306/J.AFS.2018.0596

its derivatives, serving the role of phytohormones. Another group of enzymes comprises lipases, which catalyse hydrolysis of water insoluble triacylglycerols. This reaction takes place in the water interphase and leads to the formation of fatty acids, diacylglycerols, monoacylglycerols and glycerol. Lipases also catalyse hydrolysis of water soluble, short-chain esters of carboxylic acids, which nevertheless progresses very slowly (Loiseau et al., 2001; Sembdner and Parthier, 1993). Thiyam et al. (2006) showed that the addition of sinapic acid supplements the antioxidant action of lower concentrations of endogenous tocopherols found in oils. Secondary metabolites, which include phenolic compounds, play important roles either as local or systemic resistance factors in protecting plants against various pathogens (Mandal et al., 2010). Literature sources include several studies concerning the antimicrobial properties of sinapic acid. Maddox et al. (2010) showed the antibacterial action of sinapic acid in studies concerning both plant and human pathogens. Those authors presented the inhibitory action of sinapic acid in relation to Xylella fastidiosa, a pathogenic bacterium responsible for considerable losses due to diseases in many crop plants. Sinapic acid inhibits the growth of Erwinia carotovora (bacterial soft rot disease). These pathogens produce enzymes causing hydrolysis of pectins binding plant cells. This causes separation of cells, which in turn results in their death, manifested in plant rot (Lyon and McGill, 1988). Sinapic acid also inhibits the growth of such bacterial strains as Escherichia coli, Enterobacter aerogens, Pseudomonas flouorescens, Bacillus subtilis, Bacillus cereus, Streptococcus lactis and Streptococcus cremoris (Nowak et al., 1992). The same authors reported that sinapin has no effect on the growth of the bacterial strains being investigated, which may suggest that a decrease in the level of sinapic acid derivatives (being in a bound form) and a simultaneous increase in sinapic acid content in the free form in rapeseeds infested with mould fungi is a defence mechanism of seeds against pathogens.

\section{CONCLUSION}

The studies concerned rapeseeds stored under adverse conditions $(13.5 \%$ moisture content, temperature $25^{\circ} \mathrm{C}$ ), which resulted in the growth of mould fungi.
Intensive growth of moulds was observed after 6 days of storage. Changes were found in the levels of sinapic acid derivatives, i.e. the primary phenolic compounds in rapeseeds. Both qualitative and quantitative changes in these compounds may be a response to the activity of fungal microflora developing in the mass of stored seeds. A decrease was observed in the levels of phenolic compounds found in the bound form (sinapin; sinapic acid methyl ester; 1,2-disinapoyl-dihexoside; 1,2-disinapoyl-hexoside and 1,2,2'-trisinapoyl-dihexoside). At the same time, an increase (by 63\%) was recorded in the contents of trans-sinapic acid, a compound with documented antimicrobial properties. This shows that appropriate storage conditions of oil raw material, such as rapeseeds, guarantees good quality in the final product, i.e. rapeseed oil.

\section{REFERENCES}

AOCS (2007). Official method Ba 2a-38, moisture and volatile matter, by air oven, in oilseed meats, meal, cake, and pellets. Official method and recommended practices of the American Oil Chemists' Society. 5th ed. USA: American Oil Chemists Society.

Appelqvist, L., Loof, B. (1972). Post-harvest handling and storage of rapeseed. In: L. Appelqvist, R. Ohlson (Eds.), Rapeseed. Amsterdam: Elsevier.

Baumert, A., Milkowski, C., Schmidt, J., Nimtz, M., Wray, V., Strack, D. (2005). Formation of a complex pattern of sinapate esters in Brassica napus seeds, catalyzed by enzymes of a serine carboxypeptidase-like acyltransferase family? Phytochem., 66, 1334-1345. https://doi. org/10.1016/j.phytochem.2005.02.031

Bell, J. M. (1993). Factors affecting the nutritional value of canola meal: A review. Can. J. Anim. Sci., 73, 679-697. https://doi.org/10.4141/cjas93-075

Engels, C., Schieber, A., Gänzle, M. G. (2012). Sinapic acid derivatives in defatted oriental mustard (Brassica june$c a$ L.) seed meal extracts using UHPLC-DAD-ESI-MSn and identification of compounds with antibacterial activity. Eur. Food Res. Technol., 234, 535-542. https://doi. org/10.1007/s00217-012-1669-z

Flakelar, C. L., Doran, G. S., Howitt, J. A., Luckett, D. J., Prenzler, P. D. (2018). Effects of storage temperature and duration on bioactive concentrations in the seed and oil of Brassica napus (Canola). Eur. J. Lipid Sci. Technol., 120, 1700335. https://doi.org/10.1002/ejlt.201700335

Gawrysiak-Witulska, M., Siger, A., Nogala-Kalucka, M. (2009). Degradation of tocopherols during near-ambient 
Siger, A., Gawrysiak-Witulska, M., Wawrzyniak, J. (2018). Changes in contents of phenolic compounds (sinapic acid derivatives) in seeds of Brassica napus L. under adverse storage conditions. Acta Sci. Pol. Technol. Aliment., 17(4), 367-375. http://dx.doi. org/10.17306/J.AFS.2018.0596

rapeseed drying. J. Food Lipid, 16, 524-539. https://doi. org/10.1111/j.1745-4522.2009.01164.x

Gawrysiak-Witulska, M., Siger, A., Wawrzyniak, J., Nogala-Kałucka, M. (2011). Changes in tocochromanol content in seeds of Brassica napus L. during adverse conditions of storage. J. Am. Oil Chem. Soc., 88, 9, 1379-1385. https://doi.org/10.1007/s11746-011-1793-0

Gawrysiak-Witulska, M., Rudzińska, M. (2012). Degradation of phytosterols during near-ambient drying of rapeseeds in a thick immobile layer. J. Am. Oil Chem. Soc., 89, 1681-1689. http://doi.org/10.1007/ s11746-012-2065-3

Gawrysiak-Witulska, M., Rudzińska, M., Siger, A., Bartkowiak-Broda, I. (2015). A high drying temperature causes degradation of sterols and tocopherols in yellow-seeded Brassica napus oils. Eur. J. Lipid Sci. Technol., 117, 483-490. https://doi.org/10.1002/ejlt.201400353

Gawrysiak-Witulska, M., Siger, A., Rudzińska, M., Stuper-Szablewska, K., Rusinek, R. (2018). The effect of self-heating on technological quality of rapeseeds. Int. Agrophys., 32, 313-323. http://doi.org/10.1515/intag-20170021

Hussein, H. S., Brasel, J. M. (2001). Toxicity, metabolism, and impact of mycotoxins on humans and animals. Toxicol., 167, 101-134. https://doi.org/10.1016/ S0300-483X(01)00471-1

Janowicz, L. (2005). Przechowywanie surowca [Raw material storage]. In: Cz. Muśnicki, I. Bartkowiak-Broda, M. Mrówczyński (Eds.), Technologia produkcji rzepaku (pp. 151-158). Warszawa: Wieś Jutra [in Polish].

Krasucki, W., Tys, J., Szafran, K., Rybacki, R., Orlicki, Ł. (2002). Wpływ różnych temperatur suszenia nasion rzepaku na ich skład chemiczny. Rośl. Oleiste, 23, 427-438.

Koski, A., Pekkarinen, S., Hopia, A., Wahala, K., Heinonen, M. (2003). Processing of rapeseed oil: effects on sinapic acid derivative content and oxidative stability. Eur. Food Res. Technol., 217, 110-114. https://doi.org/10.1007/ s00217-003-0721-4

Kozlowska, H., Zadernowski, R., Sosulski, F. (1983). Phenolic acid in oilseed flours. Nahrung/Food, 27, 449-453. https://doi.org/10.1002/food.19830270517

Kuwahara, H., Kanazawa, A., Wakamatu, D., Morimura, S., Kida, K., Akaike, T., Maeda, H. (2004). Antioxidative and antimutagenic activities of 4-vinyl-2,6-dimethoxyphenol (canolol) isolated from canola oil. J. Agric. Food Chem., 52, 4380-4387. https://doi.org/10.1021/ jf040045

Loiseau, J., Benoit, L. V., Macherel, M. H., Deunff, Y. L. (2001). Seed lipoxygenases: Occurrence and functions.
Seed Sci. Res., 11, 199-211. https://doi.org/10.1079/ SSR200176

Lyon, G. D., McGill, F. M. (1988). Inhibition of growth of Erwinia carotovora in vitro by phenolics. Potato Res., 31, 461-467. https://doi.org/10.1007/BF02357883

Maddox, C. E., Laur, L. M., Tian, L. (2010). Antibacterial activity of phenolic compounds against the phytopathogen Xylella fastidiosa. Curr. Microbiol., 60, 53-58. https://doi.org/10.1007/s00284-009-9501-0

Mandal, S. M., Chakraborty, D., Dey, S. (2010). Phenolic acids act as signaling molecules in plant-microbe symbioses. Plant Sign. Behav., 5, 359-368.

Mariod, A., Matthäus, B., Eichner, K., Hussein, I. H. (2015). Phenolic compounds of three unconventional Sudanese oils. Acta Sci. Pol. Technol. Aliment., 14(1), 63-69. http://dx.doi.org/10.17306/J.AFS.2015.1.7

Matthäus, B. (2013). Processing of virgin canola oils. In: U. Thiyam-Holländer, N. A. M. Eskin, B. Matthäus (Eds.), Canola and rapeseed. Production, processing, food quality, and nutrition (pp. 171-186). Boca Raton: Taylor \& Francis.

Nowak, H., Kujava, R., Zadernowski, R., Roczniak, B., Kozlowska, H. (1992). Antioxidative and bactericidal properties of phenolic compounds in rapeseeds. Eur. J. Lipid Sci. Technol., 94, 149-152. https://doi.org/10.1002/ lipi.19920940406

Pronyk, C., Abramson, D., Muir, W. E., White, N. D. G. (2006). Correlation of total ergosterol levels in stored canola with fungal deterioration. J. Stored Prod. Res., 42, 162-172. https://doi.org/10.1016/j.jspr.2004.12.004

PN-ISO 21527-2:2008. Microbiology of food and animal feeding stuffs - Horizontal method for the enumeration of yeasts and moulds - Part 2: Colony count technique in products with water activity less than or equal to 0.95 .

PN-EN-ISO 6887-1:2000. Microbiology of the food chain Preparation of test samples, initial suspension and decimal dilutions for microbiological examination - part 1: General rules for the preparation of the initial suspension and decimal dilutions.

PN-R-66151:1990. Industrial oil plants. Double low rape seeds.

Salunkhe, D. K., Adsule, R. N., Chavan, J. K., Kadam, S. S. (1992). World oilseeds. Springer Science \& Business Media.

Sembdner, G., Parthier, B. (1993). The biochemistry and the physiological and molecular actions of jasmonates. Ann. Rev. Plant Physiol. Plant Mol Biol., 44, 569-589.

Siger, A., Czubiński, J., Dwiecki, K., Kachlicki, P., Nogala-Kałucka, M. (2013). Identification and antioxidant activity of sinapic acid derivatives in Brassica napus L. 
Siger, A., Gawrysiak-Witulska, M., Wawrzyniak, J. (2018). Changes in contents of phenolic compounds (sinapic acid derivatives) in seeds of Brassica napus L. under adverse storage conditions. Acta Sci. Pol. Technol. Aliment., 17(4), 367-375. http://dx.doi. org/10.17306/J.AFS.2018.0596

seed meal extracts. Eur. J. Lipid Sci. Technol., 115, 10, 1130-1138. https://doi.org/10.1002/ejlt.201300077

Siger, A., Kaczmarek, A., Rudzińska, M. (2015). Antioxidant activity and phytochemical content of cold-pressed rapeseed oil obtained from roasted seeds. Eur. J. Lipid Sci. Technol., 117, 1225-1237. https://doi.org/10.1002/ ejlt.201400378

Siger, A., Michalak, M., Rudzińska, M. (2016). Canolol, tocopherols, plastochromanol-8 and phytosterols content in residual oil extracted from rapeseed expeller cake obtained from roasted seed. Eur. J. Lipid Sci. Technol., 118, 1358-1367. https://doi.org/10.1002/ejlt.201500314

Siger, A., Józefiak, M. (2016). The effects of roasting and seed moisture on the phenolic compound levels in coldpressed and hot-pressed rapeseed oil. Eur. J. Lipid Sci. Technol., 118, 1952-1958. https://doi.org/10.1002/ejlt. 201500249

Rękas, A., Ścibisz, I., Siger, A., Wroniak, M. (2017). The effect of microwave pretreatment of seeds on the stability and degradation kinetics of phenolic compounds in rapeseed oil during long-term storage. Food Chem., 222, 43-52. https://doi.org/10.1016/j.foodchem.2016.12.003

Tańska, M., Rotkiewicz, D. (2003). Wpływ różnych czynników na jakość nasion rzepaku. Rośl. Oleiste, 24, 595-616.

Thiyam, U., Stockmann, H., Schwarz, K. (2006). Antioxidant activity of rapeseed phenolics and their interactions with tocopherols during lipid oxidation. J. Am. Oil Chem. Soc., 83, 523-528. https://doi.org/10.1007/ s11746-006-1235-6
Thiyam, U., Pickardt, C., Ungewiss, J., Baumert, A. (2009). De-oiled rapeseed and a protein isolate: characterization of sinapic acid derivatives by HPLC-DAD and LC-MS. Eur. Food Res. Technol., 229, 825-831. https://doi.org/ 10.1007/s00217-009-1122-0

Tys, J., Rybacki, R. (2001). Rzepak - jakość nasion. Procesy zbioru, suszenia, przechowywania. Acta Agroph., 44, 33-38.

Wanasundara, U., Amarowicz, R., Shahidi, F. (1994). Isolation and identification of an antioxidative component in canola meal. J. Agric. Food Chem., 42, 1285-1290. https://doi.org/10.1021/jf00042a006

Wawrzyniak, J., Ryniecki, A., Gawrysiak-Witulska, M. (2013). Kinetics of mould growth in the stored barley ecosystem contaminated with Aspergillus westerdijkiae, Penicillium viridicatum and Fusarium poae at 23-30 ${ }^{\circ}$ C. J. Sci. Food Agric., 93, 895-901. https://doi. org/10.1002/jsfa.5820

Wawrzyniak, J., Gawrysiak-Witulska, M., Ryniecki, A. (2018a). Management control points related to the lag phase of fungal growth in a stored rapeseed ecosystem. J. Am. Oil Chem. Soc., 95, 9, 1223-1235. https://doi. org/10.1002/aocs. 12130

Wawrzyniak, J., Waśkiewicz, A., Ryniecki, A. (2018b). Evaluation of critical points of mould growth and mycotoxin production in the stored barley ecosystem with a hazardous initial microbiological state of grain. J. Stored Prod. Res., 77, 166-176. https://doi.org/10.1016/j.jspr. 2018.04.008 